\title{
Who Votes After Their Registration is Cancelled? Evidence from North Carolina*
}

\author{
Kevin Morris
}

August 19, 2020

\begin{abstract}
Voter list maintenance has received increasing attention in the popular press and from advocacy groups in the past few years. Little scholarly work, however, has detailed who is removed - or "purged" - despite no change in their legal eligibility to vote. By leveraging voter registration and provisional ballot data from North Carolina we identify individuals who were removed from the rolls between 2010 and 2016 despite no apparent change in their eligibility to vote and cast a provisional ballot in the 2016 presidential election. Although we find that minority voters were less likely than white voters to be removed overall, they were significantly more likely to cast a provisional ballot after being removed. Minorities who voted after being removed were also substantially less likely to have their provisional ballots counted than white voters. This paper presents the first evidence that imprecise voter list maintenance might disproportionately disenfranchise voters of color.
\end{abstract}

\footnotetext{
*Prepared for the 2020 Election Science, Reform, and Administration Conference. Draft paper — please do not cite. The author thanks Lia Merivaki, Myrna Pérez, and Eliza Sweren-Becker for their comments and feedback. All errors are my responsibility.
} 


\section{Introduction}

In 2016, federal appellate judges in the U.S. 4th Circuit Court of Appeals struck down North Carolina's voter identification law. The three-judge panel ruled the law unconstitutional, frankly arguing that it "target[ed] African Americans with almost surgical precision." The voter ID law passed in North Carolina was just one example of increased efforts to restrict access to the ballot box around the country. From attempts to limit student voting in New Hampshire to cutbacks in early voting in Florida, many states have made voting harder in the past decade. Many of these policies have been studied in great detail, often finding racially disparate effects.

The potentially disenfranchising consequences of voter list maintenance, however, have been less studied despite interest from the popular press. The effects of wrongful purges — the cancellation of the registration of a voter whose eligibility to vote has not changed — are largely unexplored in the literature. The past decade has seen much research on how other restrictive electoral systems, such as voter ID laws (e.g. Rocha and Matsubayashi 2014; Hicks et al. 2015) and the curtailing of early voting (e.g. Herron and Smith 2014; Weaver 2015), are shaping the electorate. The same cannot be said of voter removals: though some research on aggregate voter list maintenance from the Brennan Center (Brater et al. 2018; Morris 2019) and others exists (see, for instance, Pettigrew and Stewart III 2017) the literature has not yet identified whose registrations are cancelled despite no change in their legal eligibility to vote.

Using individual-level records from the North Carolina registered voter file and individuallevel provisional ballot data, this paper identifies a subset of individual voters who were "wrongfully purged" in North Carolina between 2010 and 2016. We define wrongful purges

as the cancellation of voter registrations despite no change in a voter's legal eligibility to cast a ballot. According to North Carolina General Statutes $\S 163-55$, U.S. citizens who are 18 years or older, have lived in their current county for at least 30 days before an election, 
and are not currently serving a sentence for a felony conviction are eligible to vote. If none of these factors change between two elections, a voter's eligibility to vote has similarly not changed. Although their eligibility to vote has not changed, however, some individuals might nevertheless be removed from the rolls. Understanding whether these wrongful purges occur, whether certain demographic groups are more likely to fall victim to them, and whether the provisional ballot process offers any protection is of key importance for understanding the implications of imprecise election administration.

Identifying all wrongful purges is likely impossible: if an individual was removed from the rolls between 2010 and 2016 but made no attempt to vote in 2016, the administrative data on which this study relies cannot identify her. Similarly, voters wrongfully removed between 2010 and 2016 who re-registered in advance of the 2016 election will be missed by this approach. Instead of attempting to identify all wrongfully purged voters, we focus on a subset of wrongfully purged voters: those who attempted to vote after being removed. Nevertheless, this approach allows us to identify the individuals who were most threatened by wrongful purges: those whose ability to cast a ballot was actually impeded on election day. As we will see, the provisional ballots of half of these individuals were rejected.

\section{Voter Registration and Database Quality}

With the exception of North Dakota, each state in the United States requires that voters register to vote prior to casting a ballot. In some states, such as Wisconsin, voters are allowed to register to vote on election day. In most states, however, voters must register to vote days or weeks before the election. These additional administrative steps imposed on a would-be voter before she can cast a ballot have been shown to lower turnout by as much as five percentage points (Ansolabehere and Konisky 2006). By registering to vote, a voter attests to her legal right to cast a ballot and the registration serves as confirmation of eligibility (Wolfinger and Rosenstone 1980). 
There is growing evidence, however, that the registered voter files may include erroneous data. Ansolabehere and Hersh (2010), for instance, demonstrated that many records are missing key information necessary to confirm an individual's eligibility to vote, such as their date of birth. Merivaki (2019) demonstrates that the timing of a voter's registration can impact whether a registration is cancelled, while Cao, Kim, and Alvarez (2020) argues that the decentralized nature of voter list maintenance gives rise to geographic discrepancies in the quality of voter registration data.

Inaccuracies in the registered voter file can have serious implications for voter participation. An incorrect address, for instance, might leave a voter less likely to receive the sorts of mailers long shown to increase electoral participation (see, for instance, Gerber and Green 2000). Potential data errors caused major concern in the leadup to the 2018 election in Georgia, where then-Secretary of State Brian Kemp suspended thousands of registration for imperfect matches between government data bases (Enamorado 2018). And as Merivaki (2020) demonstrates, incomplete information in registration records - such as the last time a voter participated - could set eligible voters on the path to wrongful cancellation due to an inaccurate assessment of inactivity.

Although errors in registration databases can cause many different problems, one error trumps all others: the cancellation of the registration of an individual whose eligibility to vote has not changed - in other words, a wrongful purge. Election administrators generally determine who should be removed from the voter roll based either on direct correspondence from a voter or by matching voter registration records with records from other sources, such as the National Change of Address database (Brater et al. 2018). Problems arise, however, when these data sources do not have enough identifying information to rule out false positives. In one highly publicized example, Texas used "weak" matches to the Social Security Master Death List to identify dead voters in 2012 - and ended up threatening the registration of voters who were still very much alive. These weak matches were concentrated in minority communities (Olsen 2012). The Lone Star State made waves again in 2019 when 
they "identified" tens of thousands of noncitizens on their rolls. The matching data, however, was fundamentally flawed: by matching against old records, they identified individuals who had become naturalized citizens and were legally eligible to vote (Ura 2019). Similar data errors led to wrongful purges in Florida in 2000 that were likely biased against Black voters (Stuart 2004), and Arkansas used erroneous data to wrongfully purge thousands of formerly incarcerated individuals in 2016 (Boozer 2016).

Bad data are not the only way in which voters can be erroneously removed from the rolls. The potential for wrongful purges is particularly important in states like North Carolina with use-it-or-lose-it voter registration provisions. In these states, states need no affirmative information that an individual's eligibility to vote has changed in order to begin the cancellation process. Instead, if voters go a few elections without participating, the state begins the cancellation process by sending them a postcard. If a voter fails to return the postcard and does not participate within the two subsequent federal election cycles, her registration can then be cancelled. ${ }^{1}$ These use-it-or-lose-it laws pose potentially bigger threats to the registrations of voters who infrequently participate, or who live in areas with unreliable mail service. Although the National Voter Registration Act of 1993 dictates that no voter shall be removed on the basis of failure to vote alone, the Supreme Court upheld Ohio's use-it-or-lose-it provision in 2018 in Husted v. A. Philip Randolph Institute.

Although inaccurate data and use-it-or-lose-it laws might increase wrongful purges, federal law provides some protection against the cancellation of eligible voters' registrations. Section 203 of the Help America Vote Act (2002) permits voters whose names are not on the rolls to cast a provisional ballot, but these provisional ballots are rejected at high rates (Kimball,

\footnotetext{
${ }^{1}$ The North Carolina voter registration website describes the state's process this way: "If a county board of elections has not had any contact with a voter for a period of two federal election cycles, then the voter will be sent a forwardable address confirmation mailing. The voter will be required to return the confirmation mailing within 30 days of the mailing. If the confirmation mailing is not returned by the voter within that time, or the mailing is returned by the postal system as undeliverable, then the voter's record will be marked inactive in the voter registration database. Inactive voters are still registered voters. If an inactive voter presents to vote, the person will be asked to update his or her address with the board of elections. In the event that an inactive voter remains in this status for another two federal election cycles (meaning the county board still has no contact with the voter), then the voter will be removed as a voter in the county."
} 
Kropf, and Battles 2006; Merivaki and Smith 2016, 2020). Though these provisional ballots are meant to be a "failsafe" for voters, in reality they seem to offer little protection against a wrongful purge.

\section{What We Know About Removals}

There has been relatively little scholarship to-date assessing the characteristics of removed voters, or the representational consequences of voter list maintenance. What little research has been done has relied on county-level estimates of removed voters from the U.S. EAC's Election Administration and Voting Survey (EAVS).

Reports from the Brennan Center (Brater et al. 2018; Morris 2019) leverage this data to demonstrate that removal rates of voters increased in certain parts of the country in the wake of the 2013 Supreme Court decision in Shelby County v. Holder. Prior to 2013, Section 5 of the 1965 Voting Rights Act required jurisdictions with a history of racially discriminatory electoral practices to "preclear" any changes to their election administration with the U.S. Department of Justice or a federal court. Shelby County struck down the formula used to determine which jurisdictions were subject to Section 5, effectively nullifying the preclearance condition. Brater et al. (2018) and Morris (2019) demonstrate that jurisdictions formerly covered by Section 5 began removing voters at substantially higher rates in the years following the decision.

Conclusions drawn from the EAVS data, however, should be taken with a grain of salt. Stewart III (2018) demonstrates that "states may report numbers to the EAC that are incorrect, or at least incomparable" (p. 1). The Brennan Center's research utilizes a difference-indifferences model that accounts for between-jurisdiction variability in reporting practices, but Stewart III (2018) cautions against using the EAVS in cross-sectional studies of voter removals. Stewart III (2019) similarly finds that the EAVS data might not be uniformly reported across the country. Again using the EAVS data, Pettigrew and Stewart III (2017) 
finds that different states adopt different paradigms when it comes to voter list maintenance and the removal of voters.

In addition to problems with the EAVS data, analyzing voter removals at the county-level poses theoretical problems. It is unlikely that voter removals occur uniformly across a given jurisdiction. Removals occur when a jurisdiction has reason to believe that a voter's eligibility to vote has changed - generally, that she has died, moved, or been convicted of a felony offense. We would therefore expect that older voters and voters in mobile communities would be removed at higher rates than other sorts of voters. County-level measurement may mask the underlying dynamics at play.

Ashenfelter and Kelley (1975) incorporates individual-level survey data with county-level characteristics to understand how list maintenance practices influenced turnout in the 1960 and 1972 elections. While they do not estimate how many individuals were removed from the list (wrongfully or otherwise), they do find that voters who lived in jurisdictions with more aggressive maintenance practices turned out at lower rates. These effects were apparently concentrated among younger voters.

Although little work has been done on how voter removals play out at the sub-county level, work on provisional ballots perhaps casts light on the ramifications of wrongful purges. As Pew Center on the States (2009) shows, more than 45 percent of provisional ballots cast in the 2008 general election were cast because voters were not registered. There are many potential reasons for this. We cannot know if the voter registered too close to the deadline, thought his registration would be automatically update when he moved, or if he was improperly removed Nevertheless, it is clear that many voters who cast provisional ballots do so because of problems with their registrations. Moreover, Shaw and Hutchings (2013) shows that voters of color are more likely than white voters to face these problems.

Merivaki and Smith (2020) leverages the same provisional ballot data used in this paper to examine individual-level determinants of provisional ballot usage in North Carolina. They 
show that roughly 9 percent of provisional ballots cast on election day in 2016 were cast because the voter had been "previously removed" from the rolls. More than 60 percent of these ballots were cast because there was "no record of registration." These large figures indicate that a not-insignificant number of provisional ballots are cast because of voters either being removed or not showing up on the rolls at all.

Although Merivaki and Smith (2020) examines the demographics of voters who cast a provisional ballot on election day in 2016, they do not compare the demographics of this group to the overall electorate in the state. They show, for instance, that 61 percent of provisional ballots were cast by white North Carolinians. Although most provisional ballots were cast by white voters, white voters made up 69 percent of all registered voters - meaning that white voters were relatively less likely to cast a provisional ballot than voters of other races. Black voters, on the other hand, made up just 22.5 percent of registered voters in 2016, but cast a third of the provisional ballots. These discrepancies are compounded by the findings in Merivaki and Smith (2020): not only were nonwhite voters more likely to end up casting a provisional ballot, they were less likely to have that provisional ballot counted.

The existing literature thus implies that racially disparate voter removals might be stalking our elections despite our inability to detect it. This paper takes us beyond what previous literature can tell us. Firstly, we begin with a discussion of the demographics of voters whose registrations are canceled. To the best of our knowledge, this is the first time removals have been studied at the individual-level for any state. We then move beyond the discussion of any removal to a discussion of wrongful purges. By studying the characteristics of voters who are removed from the rolls and subsequently vote at the address at which they were previously registered, we can understand the voters most at risk of wrongful purges. Finally, we ask whether or not the provisional ballots of wrongfully purged voters are ultimately counted. 


\section{Methodology and Data}

Our primary data comes from the North Carolina Registered Voter file. As discussed above, the "life cycle" of a voter removal is generally around 6 years. After a county has reason to believe a voter is no longer eligible, they send a mailer to the voter in question. If a voter neither responds to the mailer nor votes in the subsequent two federal election cycles, she can be removed. A voter who fails to return a mailer sent in early 2011, for instance, could be removed only if he voted in neither 2012 nor 2014 - therefore making the 2016 election the first federal election in which he might no longer be on the rolls. For this reason, we examine voters who were registered as of the 2010 election, but were no longer registered on November 8, 2016.

The voter file contains many individual-level characteristics, including: age; gender; partisan affiliation; and self-reported race. We use these characteristics to understand what populations were most likely to be removed. To better understand the types of communities at greatest risk of being removed or wrongfully purged, we also geocode ${ }^{2}$ voters in the voter file to their home census tract. Doing so allows us to control for and investigate individual- and neighborhood-level characteristics.

\section{Removed Voters}

In the North Carolina Registered Voter File, voters are assigned unique identification numbers (NCIDs). These numbers are constant across time, and are not re-assigned to new voters after an individual has been removed. Voters retain these numbers even when they move to a different county in North Carolina. We compare snapshots of the registered voter file from November 2, 2010, and November 8, 2016. Voters are considered "removed" if they were registered (actively or inactively) in 2010, but their NCID is not associated with

\footnotetext{
${ }^{2}$ Geocoding is done using the SmartyStreets product. Geocoding is considered successful when it achieves an accuracy associated with either an 8 or 9 digit zip-code; geocodes for other voters are discarded. We successfully geocode $96.4 \%$ of the addresses in the 2010 voter file.
} 
a registered voter in 2016. We begin with a discussion of the demographics of all removed voters.

\section{Wrongfully Purged Voters}

As discussed above, a voter is considered wrongfully purged if they were removed from the rolls despite no change in their legal eligibility to cast a ballot. Voters become ineligible to vote when they move, die, or are convicted of a felony offense. The registered voter file alone cannot tell us who was removed despite no change in their eligibility. We identify individuals who were wrongfully purged by examining individual-level provisional ballot data made available by the State Board of Elections. These records, taken from the 2016 general election, indicate which individuals cast a provisional ballot; their current address; why they were required to cast a provisional ballot; whether the ballot was counted; and any reason for the ballot's rejection.

We identify someone as incorrectly purged if they were removed between 2010 and 2016 and cast a provisional ballot in 2016 at the address at which they were registered in 2010 . These individuals had obviously not died, and their provisional ballot address attests to the fact that they did not move. The only other reason for which they might have been "correctly" removed is if they were convicted of a felony. Although the North Carolina voter file gives some indication of why voters are removed, there is reason to suspect that the data is not always correct: dozens of voters who cast provisional ballots in 2016 were removed between 2010 and 2016 because the state thought they had died. Nevertheless, the Supplemental Information replicates the main analyses from this paper but excludes anyone removed for a felony conviction from the wrongfully purged group.

Matching the provisional ballot data to the list of removed voters is not entirely straightforward: many of the provisional ballot records do not include voters' registration numbers, even for formerly registered voters. Moreover, the address form in the provisional ballot data 
is a free-text field, which makes matching on the string addresses alone fraught with false negatives. To match these datasets, we perform four passes over the data.

We start by matching the string address and voter ID numbers between the two datasets. The records that do not match are passed to the second match.

In the second match, we match on voter ID numbers and the latitude and longitude of geocoded addresses in the voter file and provisional ballot data. The records that do not match are passed to the third match.

Because $47 \%$ of provisional ballots cast did not have a voter ID number associated with them, the third and fourth matches proceed using other criteria. In the third match, we match on first and last names, and the street address. Names are processed to standardize capitalization, and all spaces and punctuation are removed from the names. The records that do not match are passed to the fourth match.

Finally, we match records based on first and last names, and latitude and longitude. All together, we identify 1,278 voters wrongfully purged between 2010 and 2016.

After identifying wrongfully purged voters, we investigate whether there any relationships between wrongfully purged voters' characteristics and the likelihood that their provisional ballot was ultimately accepted.

\section{Whose Registrations Are Cancelled?}

We start by looking for geographical differences in the rates of removals. North Carolina has 100 counties, each with some limited discretion over their voter list maintenance. Figure 1 details each county's removal rate over the 2010 - 2016 period. Although there is some geographic variation - counties at the far western tip of the state perhaps have slightly higher removal rates, while the central part of the state has lower rates - there does not appear to be a strong geographic clustering of removals. North Carolina's five largest cities 
are also shown on the map.

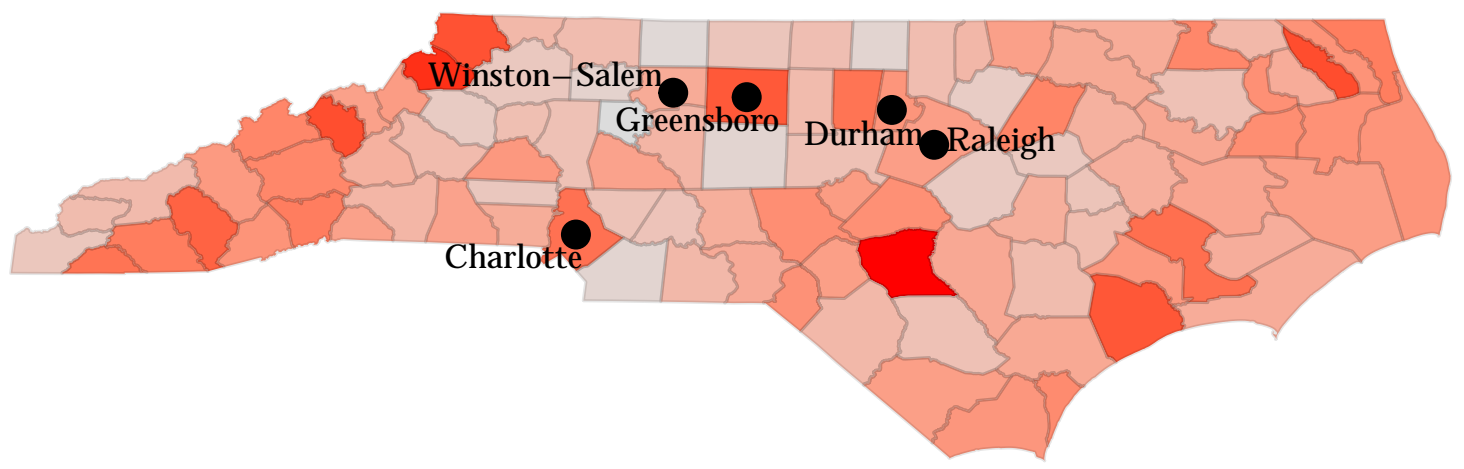

County Removal Rate

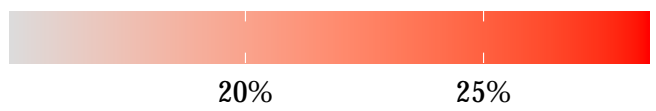

Figure 1: County-Level Removal Rates, 2010 - 2016

County removal rates range from 15.1 percent in Davie County, a suburb of Winston-Salem, to 28.5 percent in Cumberland County. Across the state, the registrations of 20.8 percent — or 1.29 million voters — were cancelled between 2010 and 2016.

Although there was not strong geographic patterning to removals, there were marked racioethnic discrepancies in cancellation rates. Figure 2 displays the share of each race or ethnicity that was removed between 2010 and 2016. Black and white ${ }^{3}$ voters were removed at roughly similar rates (20.8 and 20.3 percent, respectively). Other voters, however, were removed at higher rates: nearly one out of four (24.2 percent) of Latinos who were registered to vote in November of 2010 were no longer on the rolls as of the 2016 general election.

\footnotetext{
3"White" refers throughout this report to non-Hispanic white voters; "Black" refers to non-Hispanic Black voters.
} 
Though some of this can likely be explained by age differences (the average white voter was 50 years old in 2010, while the average Latino was just 37), the discrepancy is still substantial.

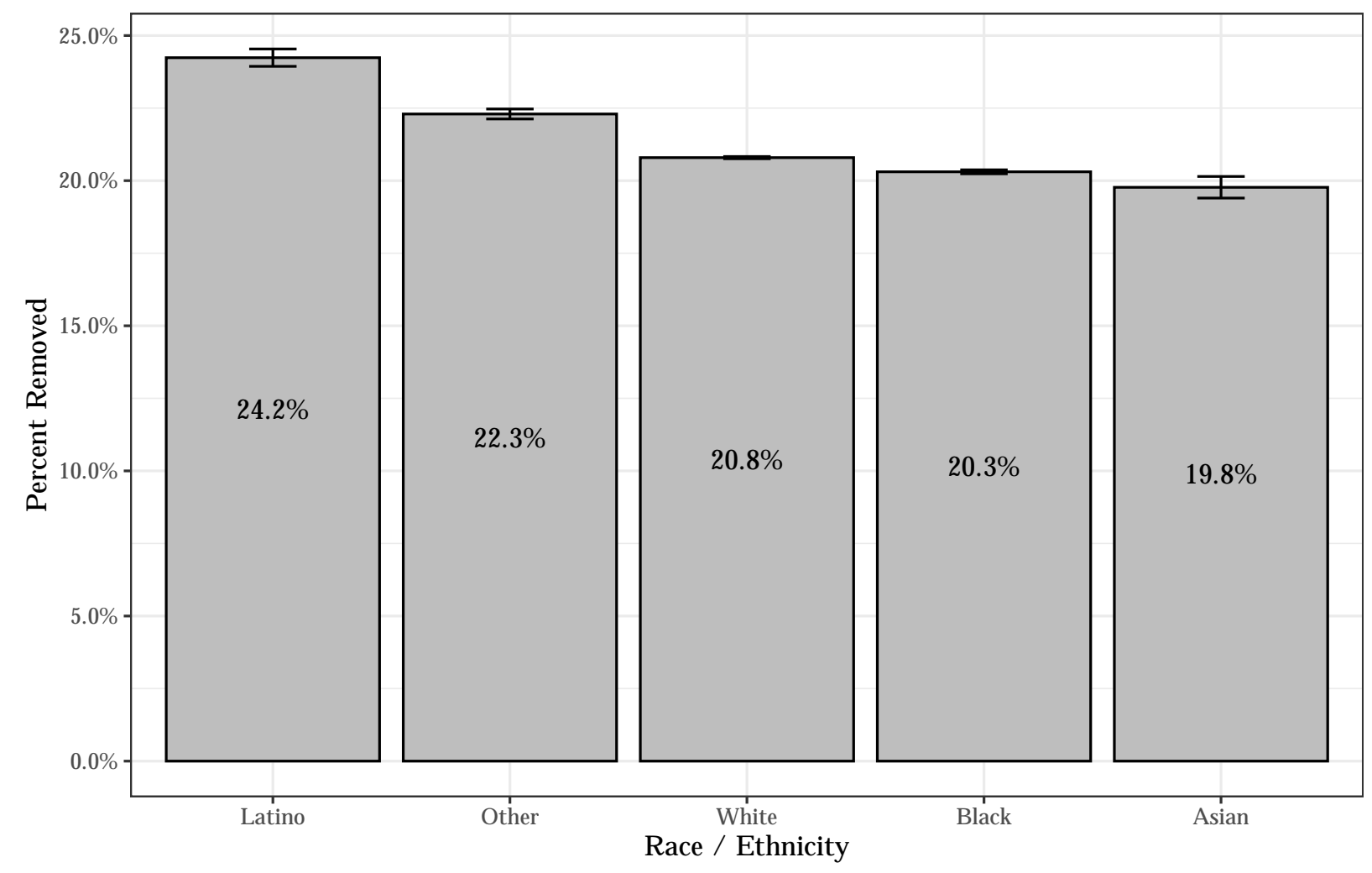

Notes: $95 \%$ confidence bars shown.

Figure 2: Percent of Voters Removed by Racioethnicity, 2010 - 2016

Figure 3 demonstrates that the young and the old were both more likely to be removed than middle-aged voters. Figure 3 plots the age distribution of voter who were and were not removed between 2010 and 2016 based on their age in 2010. Twenty-nine percent of the individuals removed between 2010 and 2016 were 65 or older in 2010; just 16 percent of voters who were not removed were 65 or over. At the other end of the spectrum, 29 percent of removed voters younger than 35 in 2010 , while only 26 percent of those who were not removed were that young. 


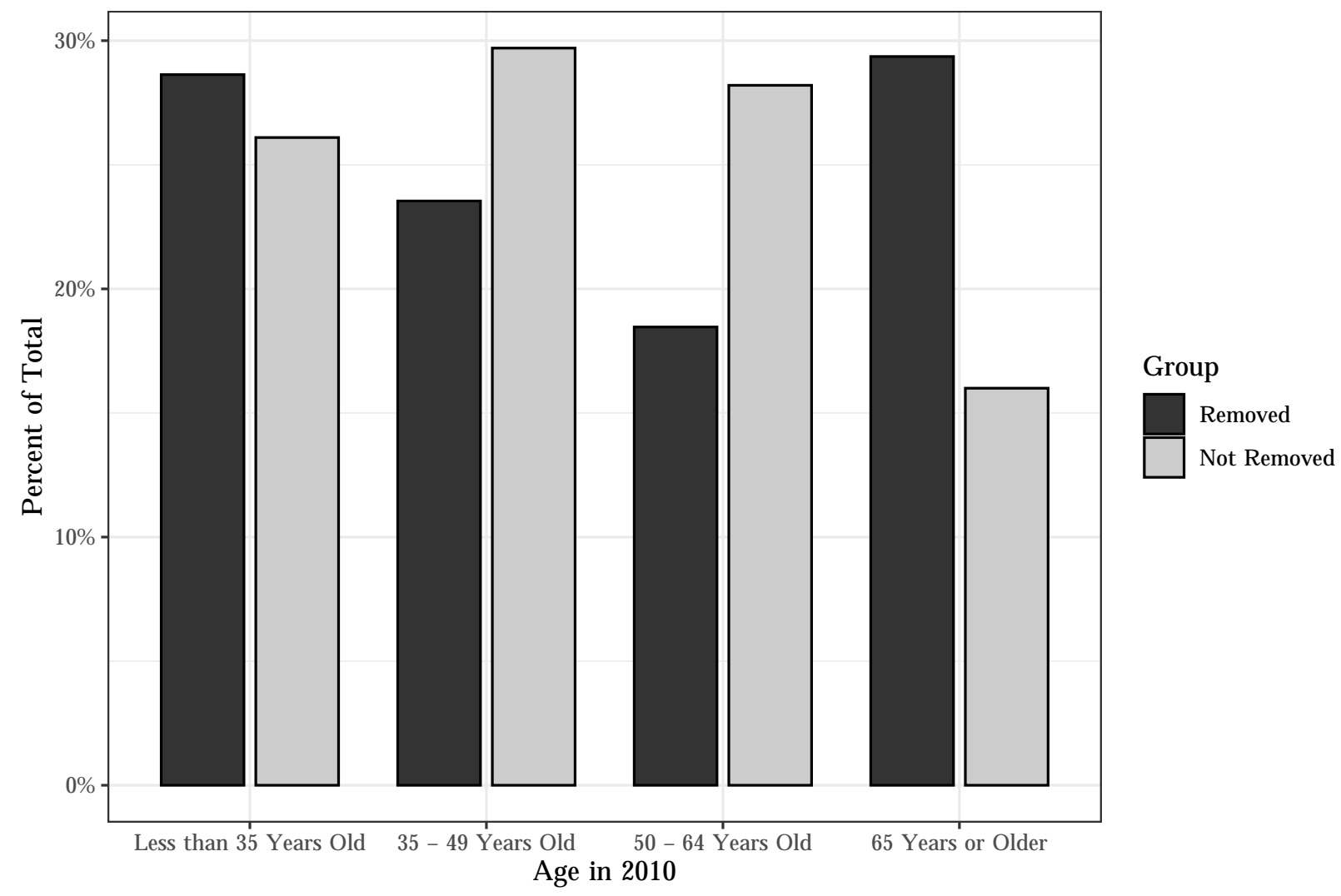

Figure 3: Age Distribution for Voters Removed and Not Removed, 2010 - 2016

This is not particularly surprising: individuals who were older in 2010 were more likely to pass away over the subsequent six years, meaning that they were more likely to come off the rolls. Younger voters, on the other hand, move more frequently and therefore are perhaps more likely to have left North Carolina and no longer be registered in the state. ${ }^{4}$

In Table 1 we combine these characteristics, as well as others, into an ordinary least squares regression. The dependent variable, which measures whether a voter was removed, is 100 if a voter was removed and 0 otherwise. We use 100 instead of 1 to aid in the interpretation of small coefficients. In Model 1, we include tests only for voters' race / ethnicity; Model 2 includes individual-level controls for age, gender, and party affiliation; Model 3 adds in estimates of voters' census tract's median income, and estimates of the share of the tract

\footnotetext{
${ }^{4}$ As noted above, voters' NCIDs remain constant when they move within North Carolina. Voters with updated registrations, therefore, are not identified in this analysis as removed.
} 
that was noncitizen, in college, or moved within the preceding 12 months. We expect that census tracts with more mobile populations (estimated with college students and movers) will have higher removal rates. These data come from the 2010 5-year American Communities Survey. Model 3 also includes county fixed effects. Model 4 replicates Model 3 but asks simply whether a voter is white or not, without providing breakouts by racial category. In each model, robust standard errors are clustered at the county level. 
Table 1: Removed Between 2010 - 2016

\begin{tabular}{|c|c|c|c|c|}
\hline & \multicolumn{4}{|c|}{ Removed } \\
\hline & $(1)$ & $(2)$ & $(3)$ & $(4)$ \\
\hline Asian & $\begin{array}{c}-1.024^{* * *} \\
(0.194)\end{array}$ & $\begin{array}{c}0.020 \\
(0.190)\end{array}$ & $\begin{array}{c}-2.178^{* * *} \\
(0.193)\end{array}$ & \\
\hline Black & $\begin{array}{c}-0.489^{* * *} \\
(0.040)\end{array}$ & $\begin{array}{c}0.416^{* * *} \\
(0.044)\end{array}$ & $\begin{array}{c}-1.816^{* * *} \\
(0.047)\end{array}$ & \\
\hline Latino & $\begin{array}{c}3.443^{* * *} \\
(0.146)\end{array}$ & $\begin{array}{c}4.361^{* * *} \\
(0.143)\end{array}$ & $\begin{array}{c}2.171^{\text {*** }} \\
(0.144)\end{array}$ & \\
\hline Other Race & $\begin{array}{c}1.503^{* * *} \\
(0.087)\end{array}$ & $\begin{array}{c}2.359^{* * *} \\
(0.089)\end{array}$ & $\begin{array}{c}1.081^{* * *} \\
(0.092)\end{array}$ & \\
\hline Nonwhite & & & & $\begin{array}{c}-1.156^{* * *} \\
(0.043)\end{array}$ \\
\hline Republican & & $\begin{array}{c}-0.884^{* * *} \\
(0.041)\end{array}$ & $\begin{array}{c}-0.316^{* * *} \\
(0.042)\end{array}$ & $\begin{array}{c}-0.133^{* * *} \\
(0.042)\end{array}$ \\
\hline Unaffiliated & & $\begin{array}{c}2.305^{* * *} \\
(0.044)\end{array}$ & $\begin{array}{c}2.269^{* * *} \\
(0.044)\end{array}$ & $\begin{array}{c}2.492^{* * *} \\
(0.044)\end{array}$ \\
\hline Male & & $\begin{array}{c}2.371^{* * *} \\
(0.032)\end{array}$ & $\begin{array}{c}2.420^{* * *} \\
(0.032)\end{array}$ & $\begin{array}{c}2.424^{* * *} \\
(0.032)\end{array}$ \\
\hline Age in 2010 & & $\begin{array}{c}-1.819^{* * *} \\
(0.004)\end{array}$ & $\begin{array}{c}-1.674^{* * *} \\
(0.005)\end{array}$ & $\begin{array}{c}-1.679^{* * *} \\
(0.005)\end{array}$ \\
\hline$(\text { Age in } 2010)^{2}$ & & $\begin{array}{c}0.020^{* * *} \\
(0.00004)\end{array}$ & $\begin{array}{c}0.019^{* * *} \\
(0.00004)\end{array}$ & $\begin{array}{c}0.019^{* * *} \\
(0.00004)\end{array}$ \\
\hline Percent College Students & & & $\begin{array}{c}0.805^{* * *} \\
(0.278)\end{array}$ & $\begin{array}{c}1.032^{* * *} \\
(0.278)\end{array}$ \\
\hline Median Income $(\$ 10,000 \mathrm{~s})$ & & & $\begin{array}{c}-0.391^{* * *} \\
(0.010)\end{array}$ & $\begin{array}{c}-0.366^{* * *} \\
(0.010)\end{array}$ \\
\hline Percent Moved in Past 12 Months & & & $\begin{array}{c}31.535^{* * *} \\
(0.265)\end{array}$ & $\begin{array}{c}31.416^{* * *} \\
(0.265)\end{array}$ \\
\hline Percent Non-Citizen & & & $\begin{array}{c}9.734^{* * *} \\
(0.365)\end{array}$ & $\begin{array}{c}10.048^{* * *} \\
(0.365)\end{array}$ \\
\hline Constant & $\begin{array}{c}20.794^{* * *} \\
(0.019)\end{array}$ & $\begin{array}{c}54.232^{* * *} \\
(0.114)\end{array}$ & $\begin{array}{c}43.137^{* * *} \\
(0.192)\end{array}$ & $\begin{array}{c}42.963^{* * *} \\
(0.192)\end{array}$ \\
\hline County Fixed Effects & & & $\mathrm{X}$ & $\mathrm{X}$ \\
\hline Observations & $6,200,456$ & $6,200,456$ & $5,977,100$ & $5,977,100$ \\
\hline $\mathrm{R}^{2}$ & 0.0002 & 0.045 & 0.057 & 0.056 \\
\hline Adjusted $\mathrm{R}^{2}$ & 0.0002 & 0.045 & 0.057 & 0.056 \\
\hline
\end{tabular}


When we do not control for other characteristics, Black voters registered in 2010 were 0.49 percentage points less likely to be removed than white voters. Asian voters were also less likely to be removed (1.0 points less likely), while Latinos were 3.4 points more likely to be removed than white voters. Even after adding in individual, neighborhood, and county characteristics, Latinos and voters of other races (that is, neither white, Black, Latino, or Asian) were more likely to be removed than white voters (though the under-representation of Black voters vis-à-vis white voters becomes more pronounced). Model 4 indicates that, taken as a whole, nonwhite voters were 1.6 points less likely to be removed than white voters after controlling for other sociodemographic information.

Table 1 also demonstrates that other groups were over-represented among the cancellations between 2010 and 2016. Men, for instance, were as much as 2.4 points more likely to be removed than women, while Republicans were less likely to be removed than Democrats. Voters who lived in census tracts where a higher share of residents had moved in the preceding 12 months were more likely to be removed. Voters in higher-income neighborhoods were removed at lower rates as were - surprisingly — voters in neighborhoods with a large share of college students.

\section{Who is Wrongfully Purged?}

Having established the characteristics of voters who are typically removed, we turn to a harder question: what voters are most likely to be wrongfully purged? The above models do not necessarily point to major underlying problems. If, for instance, Latinos or Democrats were more likely to move out of the state over the 2010 - 2016 period they should have higher removal rates; after all, they became ineligible at higher rates.

We expect that wrongful purge rates will be inversely related to a group's removal rate. Each marginal cancellation of a record is more likely to be wrongful, all else equal. Given that removal rates were highest for Latinos even after controlling for other characteristics, we 
might expect them to have the highest wrongful purge rates. By the same logic, we would expect these rates to be lowest among Black voters, who were the least likely to be removed. We identify incorrect purges by looking to see who attempted to cast a ballot in North Carolina after being removed. Using data from the 2016 presidential election in North Carolina, we identify 1,278 individuals who were purged between 2010 and 2016 and participated in the 2016 general election via provisional ballot. These voters lived in 90 of North Carolina's 100 counties, indicating that bad purges were not limited to a few select counties. It is important to note that 1,278 wrongful purges is an extremely conservative estimate; there are almost certainly voters were removed but did not move, die, or get convicted of a felony offense over the time period who nevertheless did not attempt to cast a provisional ballot in 2016.

Table 2 we ask what characteristics were associated with being wrongfully purged. The universe of voters in Table 2 is all voters who were removed between 2010 and 2016; the dependent variable, bad purge, measures whether the removed voter cast a provisional ballot in the 2016 general election. As before, robust standard errors are clustered at the county level and the dependent variable takes the value 100 if a voter was wrongfully purged and 0 otherwise. 
Table 2: Wrongfully Purged

\begin{tabular}{|c|c|c|c|c|}
\hline & \multicolumn{4}{|c|}{ Wrongfully Purged } \\
\hline & $(1)$ & $(2)$ & $(3)$ & $(4)$ \\
\hline Asian & $\begin{array}{l}-0.016 \\
(0.034)\end{array}$ & $\begin{array}{l}-0.052 \\
(0.034)\end{array}$ & $\begin{array}{l}-0.004 \\
(0.036)\end{array}$ & \\
\hline Black & $\begin{array}{c}0.061^{* * *} \\
(0.007)\end{array}$ & $\begin{array}{c}0.040^{* * *} \\
(0.008)\end{array}$ & $\begin{array}{c}0.052^{* * *} \\
(0.008)\end{array}$ & \\
\hline Latino & $\begin{array}{l}-0.012 \\
(0.023)\end{array}$ & $\begin{array}{c}-0.055^{* *} \\
(0.023)\end{array}$ & $\begin{array}{l}-0.032 \\
(0.024)\end{array}$ & \\
\hline Other Race & $\begin{array}{c}0.038^{* * *} \\
(0.014)\end{array}$ & $\begin{array}{c}0.005 \\
(0.015)\end{array}$ & $\begin{array}{c}0.001 \\
(0.016)\end{array}$ & \\
\hline Nonwhite & & & & $\begin{array}{c}0.037^{* * *} \\
(0.008)\end{array}$ \\
\hline Republican & & $\begin{array}{l}-0.006 \\
(0.007)\end{array}$ & $\begin{array}{l}-0.002 \\
(0.008)\end{array}$ & $\begin{array}{l}-0.006 \\
(0.007)\end{array}$ \\
\hline Unaffiliated & & $\begin{array}{c}-0.026^{* * *} \\
(0.007)\end{array}$ & $\begin{array}{c}-0.020^{* *} \\
(0.008)\end{array}$ & $\begin{array}{c}-0.024^{* * *} \\
(0.008)\end{array}$ \\
\hline Male & & $\begin{array}{c}0.045^{* * *} \\
(0.006)\end{array}$ & $\begin{array}{c}0.043^{* * *} \\
(0.006)\end{array}$ & $\begin{array}{c}0.043^{* * *} \\
(0.006)\end{array}$ \\
\hline Age in 2010 & & $\begin{array}{c}-0.003^{* * *} \\
(0.001)\end{array}$ & $\begin{array}{c}-0.005^{* * *} \\
(0.001)\end{array}$ & $\begin{array}{c}-0.005^{* * *} \\
(0.001)\end{array}$ \\
\hline$(\text { Age in } 2010)^{2}$ & & $\begin{array}{c}0.00000 \\
(0.00001)\end{array}$ & $\begin{array}{l}0.00002^{* *} \\
(0.00001)\end{array}$ & $\begin{array}{c}0.00002^{* *} \\
(0.00001)\end{array}$ \\
\hline Percent College Students & & & $\begin{array}{c}-0.142^{* * *} \\
(0.043)\end{array}$ & $\begin{array}{c}-0.146^{* * *} \\
(0.043)\end{array}$ \\
\hline Median Income $(\$ 10,000 \mathrm{~s})$ & & & $\begin{array}{c}-0.007^{* * *} \\
(0.002)\end{array}$ & $\begin{array}{c}-0.008^{* * *} \\
(0.002)\end{array}$ \\
\hline Percent Moved in Past 12 Months & & & $\begin{array}{c}-0.295^{* * *} \\
(0.044)\end{array}$ & $\begin{array}{c}-0.296^{* * *} \\
(0.044)\end{array}$ \\
\hline Percent Non-Citizen & & & $\begin{array}{c}-0.066 \\
(0.061)\end{array}$ & $\begin{array}{l}-0.075 \\
(0.061)\end{array}$ \\
\hline Constant & $\begin{array}{c}0.085^{* * *} \\
(0.003)\end{array}$ & $\begin{array}{c}0.219^{* * *} \\
(0.019)\end{array}$ & $\begin{array}{c}0.408^{* * *} \\
(0.036)\end{array}$ & $\begin{array}{c}0.413^{* * *} \\
(0.036)\end{array}$ \\
\hline County Fixed Effects & & & $\mathrm{X}$ & $\mathrm{X}$ \\
\hline Observations & $1,288,443$ & $1,288,443$ & $1,223,887$ & $1,223,887$ \\
\hline $\mathrm{R}^{2}$ & 0.0001 & 0.0004 & 0.001 & 0.001 \\
\hline Adjusted $\mathrm{R}^{2}$ & 0.0001 & 0.0004 & 0.001 & 0.001 \\
\hline
\end{tabular}


Table 2 indicates that there were substantial discrepancies in who was wrongfully purged. Black voters are especially over-represented here: although less likely than white voters to be removed generally, removed Black voters were far more likely to try to cast a ballot than removed white voters. Even after controlling for individual and community characteristics (age, party, gender, neighborhood income, neighborhood move rates, neighborhood college population, neighborhood citizenship status, and countywide averages), the wrongful purge rate among removed Black voters was 0.05 percentage points higher than for white voters. Voters of other races similarly saw elevated error rates among their removals. Taken as a whole, removed nonwhite voters were 0.04 points more likely to cast a provisional ballot in 2016 than removed white voters. Although these are small numbers, it is worth noting that just 0.085 percent of white voters were wrongfully purged. The relative magnitude of these estimates is therefore quite large.

This is especially remarkable given racial differences in turnout rates: 58.5 percent of white voters registered in 2010 cast a ballot in 2016; 55.3 percent of registered Black voters cast a ballot, and just 42.5 percent of Latinos registered in 2010 participated in 2016. Therefore, although white voters turned out at higher rates - and could therefore be more easily "revealed" as having been wrongfully purged - their wrongful purge rates were lower than those of other races / ethnicities.

Figure 4 demonstrates the number of wrongful purges per 10 thousand removals between 2010 and 2016, a graphical representation of Model 1 in Table 2. This makes the wrongful purge rates for different races visually clear. For every 10 thousand white voters removed between 2010 and 2016, 8.5 cast a provisional ballot in the 2016 midterms. That number rises to nearly 15 for each 10 thousand purged Black voters, and is lowest -7.3 and 6.9 per 10,000 removals - for Latino and Asian voters, respectively. 


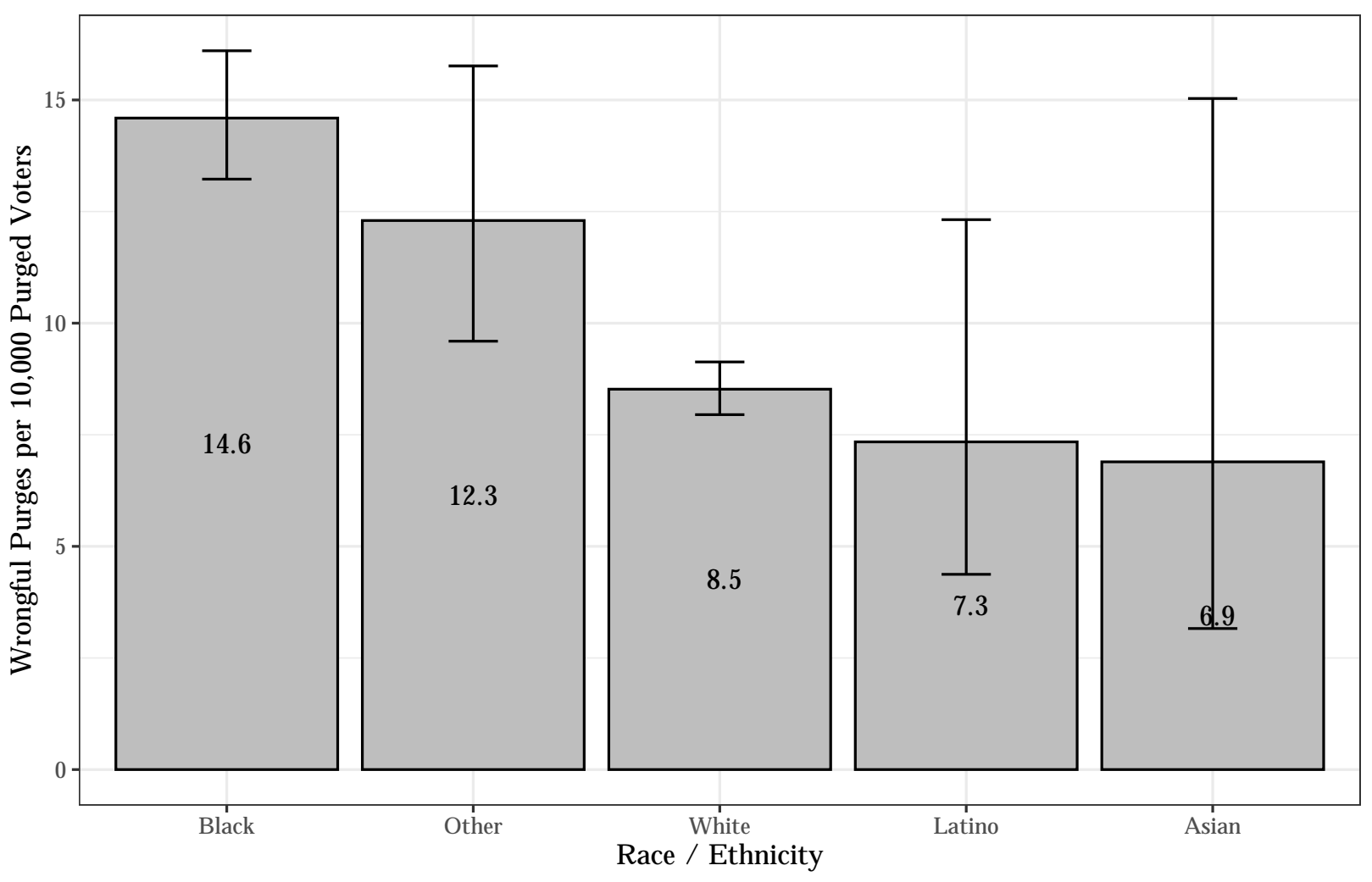

Notes: $95 \%$ confidence bars shown.

Figure 4: Provisional Ballots Cast per 10 Thousand Voters Removed, 2010 - 2016

In addition to these racial discrepancies, removed men were far more likely than women to cast a provisional ballot (by roughly 60 percent). A ten percent increase in the share of movers in a census tract is associated with a 27 percent decrease in the likelihood of a removed voter casting a ballot. Each additional $\$ 10,000$ in a neighborhood's median income is associated with an 8 percent decrease in a removed voter's likelihood of casting a provisional ballot (See Figure 5). As Figure 6 makes clear, the wrongful purges are largely clustered among removed voters who were younger than 50 in 2010; older removed voters were less likely to try to vote in 2016. 


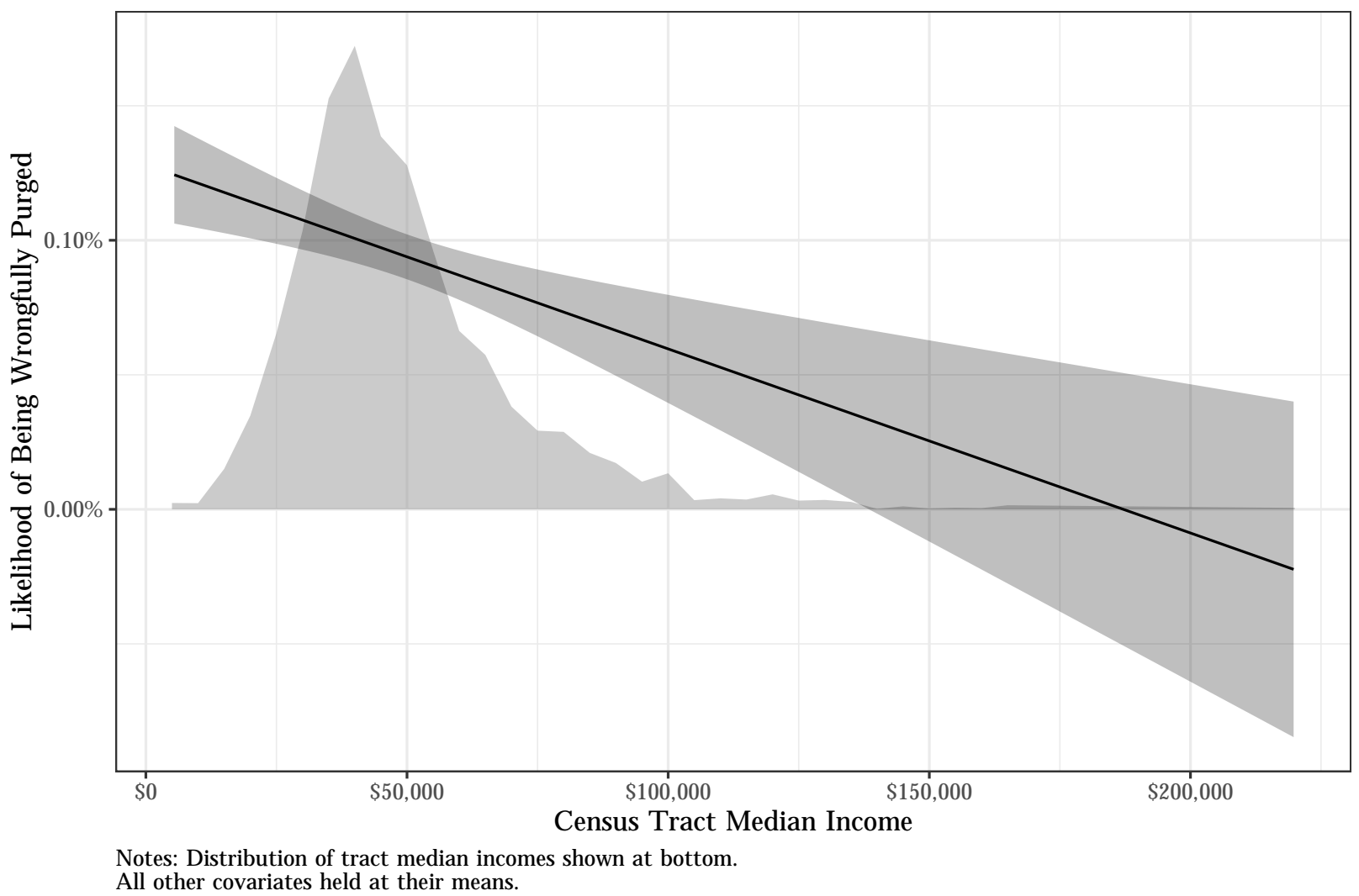

Figure 5: Marginal Effect of Census Tract Median Income on Wrongful Purge Rates 


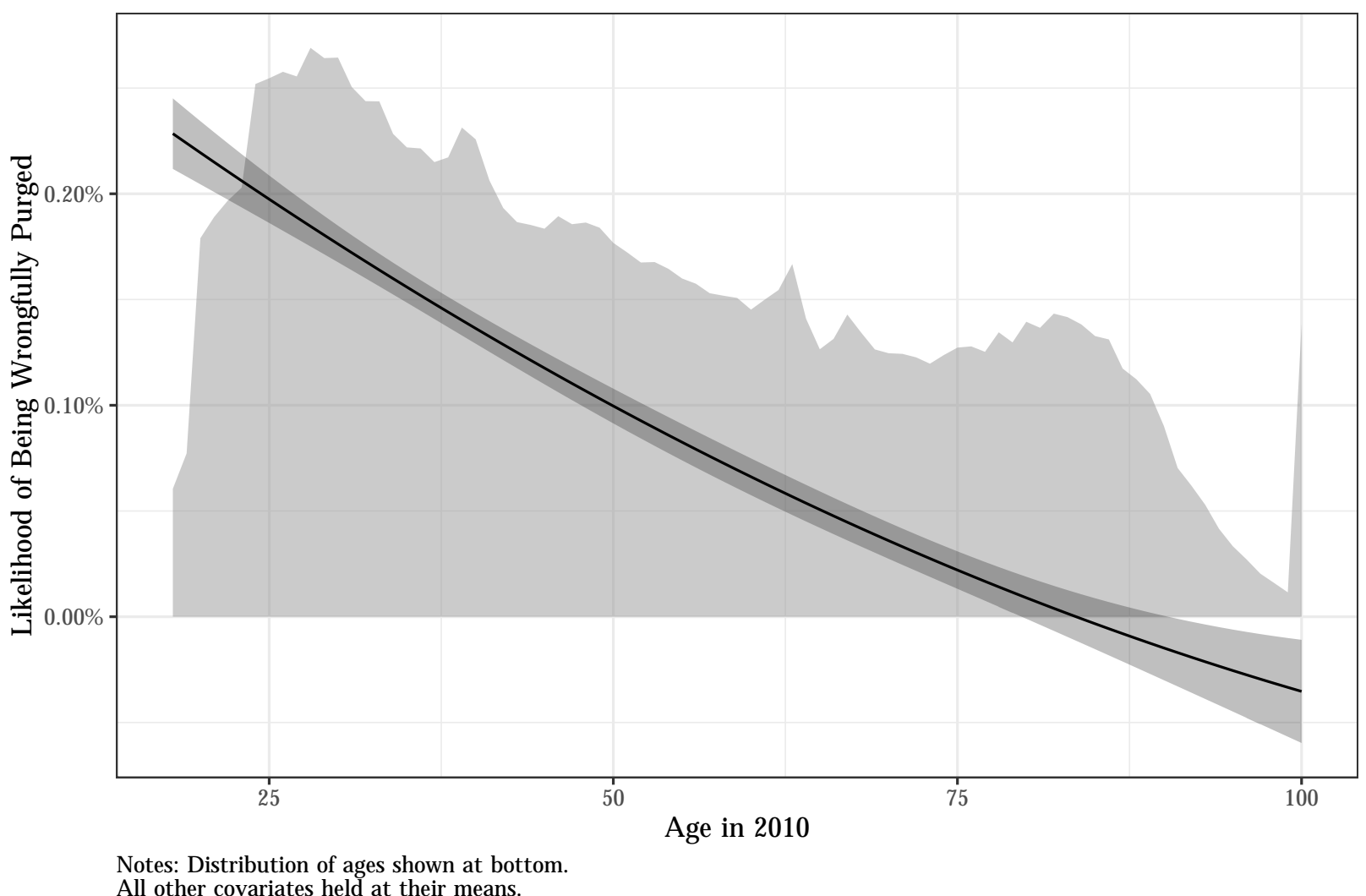

Figure 6: Marginal Effect of Age in 2010 on Wrongful Purge Rates

The provisional ballot data also indicates why a voter was required to cast a provisional ballot. Unsurprisingly, the overwhelming majority (94 percent) of these wrongfully purged voters had to cast a provisional ballot because either there was "no record of registration" or because the voter had been "previously removed." Although North Carolina election law allows voters to update their registration information and cast a regular ballot on election day, it does not allow them to re-register if they have been removed. They are thus forced to submit provisional ballots. 


\section{Whose Ballots Count? ${ }^{5}$}

Using the provisional ballot data, we can tell at the individual level which provisional ballots were counted. Although these 1,278 voters were not on the rolls for the general election in 2016, 51 percent of their provisional ballots were counted in part or in whole, while just 44 percent of all provisional ballots statewide were counted. Thus, although there more than twelve hundred incorrect purges, half of the provisional ballots were ultimately counted. It is important to note that the ultimate acceptance of a provisional ballot does not mean the voter incurred no costs. Because she was unregistered, she was unlikely to receive mailers the county sent out before the election; she had to take more time to cast a provisional ballot; and she may have needed to make a second trip to the election administration office after voting to prove her eligibility. Nevertheless, it is a positive sign that so many provisional ballots were counted.

A far less positive sign, however, are the racial discrepancies in whose provisional ballots were counted. As detailed in the past section, Black voters were substantially more likely to attempt to vote after being removed than white voters. We might expect, therefore, that a higher share of their provisional ballots would be counted. Table 3 makes clear that that expectation would be wrong. Although just 39.3 percent of provisional ballots cast by purged white voters were completely rejected, 69.4 percent of the provisional ballots cast by purged Black voters were rejected, a difference that is significant at the 99 percent level. Table 3 presents the results of an OLS regression, in which the dependent variable is 100 if a provisional ballot was rejected in whole, or 0 if it was partially accepted or accepted in whole.

In addition to the covariates included in Table 2, we here test whether the reason a voter was removed is related to the probability of their provisional ballot counting. We group the

\footnotetext{
${ }^{5}$ Because voters in North Carolina can register at polling places during early voting but not on election day, provisional ballots cast on early voting days were possibly more likely to be counted. We therefore limit this analysis to wrongfully purged voters who cast provisional ballots on election day.
} 
removal reason codes into three groups: removed because of the use-it-or-lose-it provision; removed because of a move; or removed for another reason. 
Table 3: Provisional Ballot Rejected

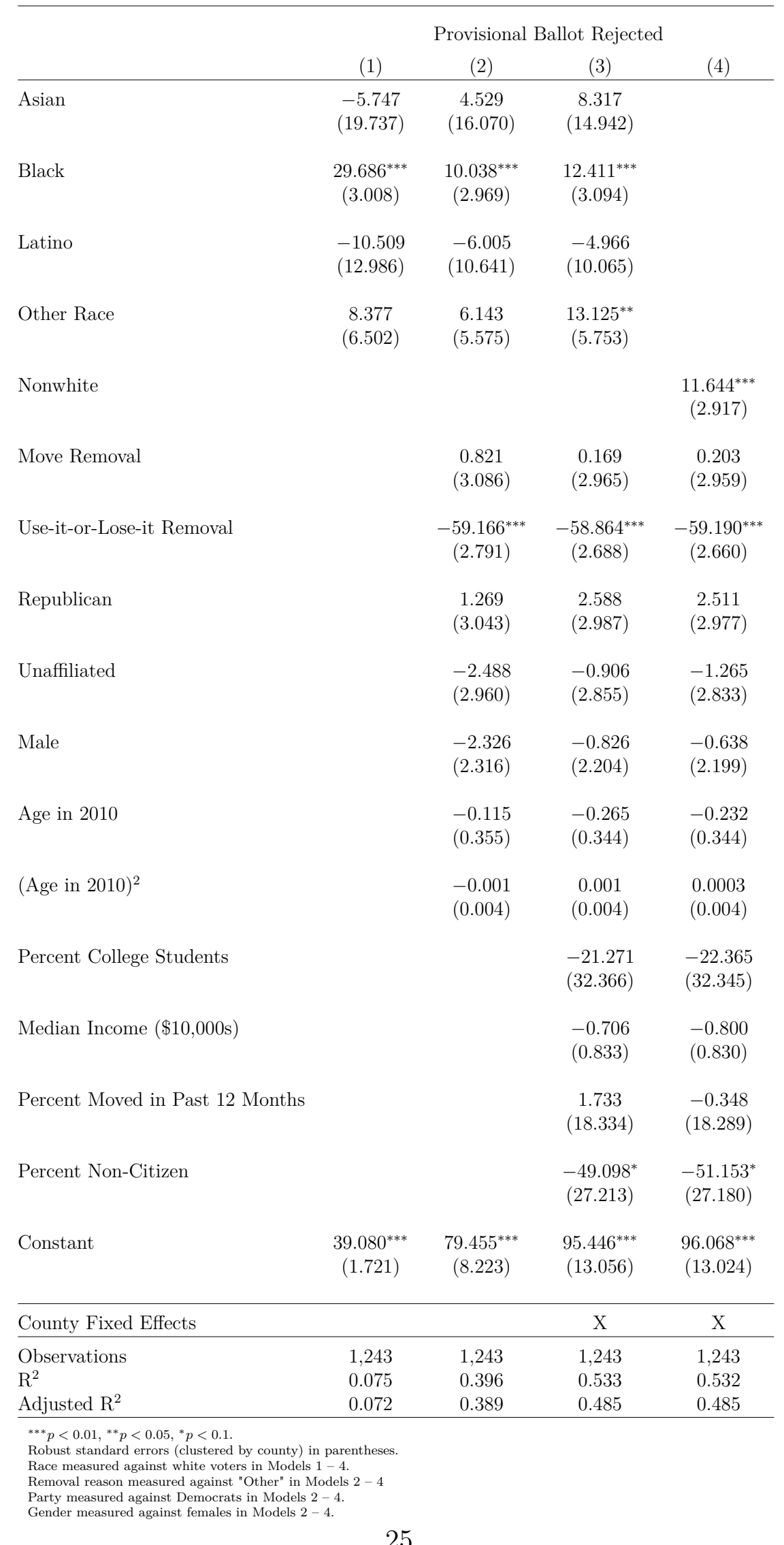


After controlling for other characteristics, Model 3 indicates that the rejection rate for wrongfully purged Black voters 12.4 percentage points higher than for white voters. Model 4, which groups all nonwhite voters together, indicates that the rejection rate for wrongfully purged nonwhites was collectively 11.6 points higher than for wrongfully purged white voters. Therefore, not only were nonwhite (and especially Black) voters substantially more likely to be wrongfully purged than white voters; even after being wrongfully purged, their ballots were far less likely to be counted.

Table 3 also indicates that provisional ballots cast by voters removed because of the state's use-it-or-lose it provision were far less likely to have their ballots rejected. This likely arises from the explicit text in North Carolina's General Statues which allows voters who try to vote after being removed under the use-it-or-lose it provision to cast a ballot if they attest to the fact that they never moved (North Carolina General Statutes 163-82.14(d)(3)). On the other hand, §163-82.15(f) would seem to cover all wrongfully purged voters who attest to not having moved. ${ }^{6}$ It is therefore not clear why some provisional ballots are counted more often than others.

In Appendix A, we re-run the models presented in Tables 2 and 3, but a removed voter is only considered wrongfully purged if they cast a provisional ballot and they were not removed for a felony conviction. The information is clearly sometimes wrong; more than 60 of our wrongful purges were marked as deceased between 2010 and 2016, though their actions on election day in 2016 seem to indicate otherwise. Nevertheless, our robustness check relies on this state-provided explanation. Even when we do not consider provisional ballots cast by individuals removed for felony convictions wrongful purges, Black voters are over-represented among the wrongfully purged. Their provisional ballots are also less likely to be counted.

\footnotetext{
${ }^{6}$ General Statute 163-82.15(f) reads as follows: "When Registrant Disputes Registration Records. - If the registration records indicate that the registrant has moved outside the precinct, but the registrant denies having moved from the address within the precinct previously shown on the records, the registrant shall be permitted to vote at the voting place for the precinct where the registrant claims to reside, if the registrant gives oral or written affirmation before a precinct official at that voting place."
} 


\section{Discussion}

Over the past few years, voter list maintenance has received increasing attention in the popular press and, slowly, from scholars. Nevertheless, the potential implications of list maintenance gone awry have been understudied relative to other facets of the American electoral system such as polling place accessibility, voter ID laws, and early voting. This is likely an issue of data accessibility. Using voter file data alone, it is impossible to distinguish a proper removal — one in which a voter's eligibility to vote changed — from a wrongful one. Only by examining future interactions with the state in which a voter re-affirms her earlier status or indicates a changed status (such as a move) can we identify whether her eligibility changed.

By leveraging a post-removal interaction with the state, this paper provides the first estimates of which voters are removed despite no change in their eligibility. The approach taken certainly misses some wrongfully purged voters. Because wrongfully purged voters are likely to be marginal voters - after all, many of them were removed because of inactivity — they were perhaps unlikely to "reveal" themselves by voting in 2016. However, by focusing only on wrongfully purged voters who actually wanted to participate, we can home in on the wrongfully purged voters at greatest risk of being disenfranchised on election day. And, as the analyses presented in this paper demonstrate, this is not simply a potential risk: half of the provisional ballots cast by wrongfully purged voters went uncounted.

This paper uncovers very large racial discrepancies in wrongful purge rates. For every 10,000 Black voters removed between 2010 and 2016, 15 tried to cast a provisional ballot in the presidential contest of 2016. For white voters, that number is just 8.5. Very little of this racial discrepancy can be explained through observable characteristics. Even after control-

ling for individual, neighborhood, and county factors, removed Black voters were more than 50 percent more likely to show up on election day in 2016 and contend that their eligibility to vote had not changed. Three out of four provisional ballots cast by Black voters were 
completely rejected; more than half of these ballots cast by wrongfully purged white voters were counted. These differences remain even after including county-level fixed effects, implying that the discrepancy does not arise from some geographic concentration of Black voters in counties where fewer provisional are counted.

Future work should develop ways of expanding our understanding of the full pool of wrongfully purged voters. Although an unknown number of these wrongfully purged voters did not try to vote in North Carolina in 2016 , they might try to do so in the future. Should a candidate come along that is highly mobilizing to these marginal voters, their wrongfully purged status might not be made known until it is too late to do anything about it.

This future research should also look beyond North Carolina and find ways to estimate wrongful purges in other parts of the country. A potential avenue for such work could use voter registration snapshots over time to identify voters who are removed and subsequently re-register at the same pre-removal address. This study implies that such an approach could be fruitful: more than half of the wrongfully purged voters who cast a provisional ballot in 2016 were re-registered at their same 2010 address by election day of 2018 .

Of course, this study only looks at the very end of what is a long process of removing eligible voters. It does not identify where the state went wrong, or the mechanisms by which eligible voters are accidentally removed. As Merivaki (2020) shows, there are many points at which errors in the voter file can set voters on a track toward removal despite no change in their eligibility. Future work should identify the precise factors leading to the cancellation of an eligible voter's registration. Of crucial importance will be the investigation of why voters of color are disproportionately impacted.

Research from the past decade has detailed that certain groups of voters consistently get the short end of the stick when it comes to electoral systems in the United States. Voters of color and lower-income voters have been shown to suffer disproportionately from voter ID laws (Hajnal, Lajevardi, and Nielson 2017), from cutbacks to early voting (Herron and 
Smith 2014), and from felony disenfranchisement (Morris 2020). We now know that, at least in North Carolina, Black voters, younger voters, and voters living in lower-income neighborhoods are more likely to be wrongfully purged. This is further compounded for Black and young voters by the disproportionate rejection of their provisional ballots. It is clear that improper voter list maintenance is one facet of the panoply of electoral practices disproportionately disenfranchising certain voters - and undermining American democracy in the process. 


\section{Appendix A}

There is one group of individuals who could have neither moved nor died between 2010 and 2016, and yet had their eligibility to vote at their 2010 address revoked: individuals who were convicted of felony offenses. Individuals convicted of felonies in North Carolina are barred from voting until they have finished their sentence. As discussed above, the North Carolina voter file indicates why most removals occurred. In this Supplemental Information, we do not consider provisional ballots cast by voters who were removed because of a felony conviction "wrongful purges", because these voters may in fact have lost the right to participate at their home address.

We do not adopt this definition in the body of this manuscript because there is reason to believe that the state may have removed these individuals incorrectly. Such wrongful felony purges have happened in other states like Arkansas (Hardy 2016). Moreover, the removal codes from North Carolina indicate errors: 61 voters who cast provisional ballots in 2016 were removed between 2010 and 2016 because the state thought they had died. Nevertheless, we here assume that these codes are not incorrect, and that every individual removed for a felony conviction was correctly removed.

In Table 4 we consider first whether racial minorities are still over-represented among the wrongfully purged (in Models 1 and 2), and secondly whether provisional ballots were still more likely to be rejected when cast by a wrongfully purged voter of color. As in the body of the manuscript, robust standard errors are clustered by county. 
Table 4: Excluding Purges for Felony Convictions

\begin{tabular}{|c|c|c|c|c|}
\hline & \multicolumn{2}{|c|}{ Wrongfully Purged } & \multicolumn{2}{|c|}{ Provisional Ballot Rejected } \\
\hline & $(1)$ & $(2)$ & $(3)$ & $(4)$ \\
\hline Asian & $\begin{array}{l}-0.229 \\
(0.449)\end{array}$ & $\begin{array}{c}0.027 \\
(0.451)\end{array}$ & $\begin{array}{l}-0.713 \\
(1.121)\end{array}$ & $\begin{array}{l}-0.001 \\
(1.201)\end{array}$ \\
\hline Black & $\begin{array}{l}0.190^{* *} \\
(0.075)\end{array}$ & $\begin{array}{l}0.167^{*} \\
(0.093)\end{array}$ & $\begin{array}{c}0.988^{* * *} \\
(0.155)\end{array}$ & $\begin{array}{c}1.450^{* * *} \\
(0.246)\end{array}$ \\
\hline Latino & $\begin{array}{l}-0.225 \\
(0.304)\end{array}$ & $\begin{array}{l}-0.303 \\
(0.306)\end{array}$ & $\begin{array}{l}-1.629 \\
(1.052)\end{array}$ & $\begin{array}{c}-2.657^{* *} \\
(1.231)\end{array}$ \\
\hline Other Race & $\begin{array}{c}0.234 \\
(0.152)\end{array}$ & $\begin{array}{c}0.043 \\
(0.167)\end{array}$ & $\begin{array}{c}0.322 \\
(0.310)\end{array}$ & $\begin{array}{c}0.532 \\
(0.446)\end{array}$ \\
\hline Republican & & $\begin{array}{c}0.044 \\
(0.086)\end{array}$ & & $\begin{array}{c}0.243 \\
(0.231)\end{array}$ \\
\hline Unaffiliated & & $\begin{array}{l}-0.095 \\
(0.086)\end{array}$ & & $\begin{array}{l}-0.056 \\
(0.228)\end{array}$ \\
\hline Male & & $\begin{array}{c}0.287^{* * *} \\
(0.066)\end{array}$ & & $\begin{array}{l}-0.036 \\
(0.173)\end{array}$ \\
\hline Age in 2010 & & $\begin{array}{c}0.035^{* * *} \\
(0.011)\end{array}$ & & $\begin{array}{c}-0.124^{* * *} \\
(0.027)\end{array}$ \\
\hline$(\text { Age in } 2010)^{2}$ & & $\begin{array}{c}-0.001^{* * *} \\
(0.0001)\end{array}$ & & $\begin{array}{l}0.001^{* * *} \\
(0.0003)\end{array}$ \\
\hline Percent College Students & & $\begin{array}{c}-4.589^{* * *} \\
(1.057)\end{array}$ & & $\begin{array}{l}-0.791 \\
(2.702)\end{array}$ \\
\hline Median Income $(\$ 10,000 \mathrm{~s})$ & & $\begin{array}{c}-0.080^{* * *} \\
(0.025)\end{array}$ & & $\begin{array}{c}0.051 \\
(0.063)\end{array}$ \\
\hline Percent Moved in Past 12 Months & & $\begin{array}{c}-3.486^{* * *} \\
(0.570)\end{array}$ & & $\begin{array}{c}0.765 \\
(1.533)\end{array}$ \\
\hline Percent Non-Citizen & & $\begin{array}{l}-0.232 \\
(0.811)\end{array}$ & & $\begin{array}{c}-6.342^{* * *} \\
(2.207)\end{array}$ \\
\hline Constant & $\begin{array}{c}-7.233^{* * *} \\
(0.038)\end{array}$ & $\begin{array}{c}-5.881^{* * *} \\
(0.427)\end{array}$ & $\begin{array}{c}-0.673^{* * *} \\
(0.081)\end{array}$ & $\begin{array}{l}2.309^{* *} \\
(0.985)\end{array}$ \\
\hline County Fixed Effects & & $\mathrm{X}$ & & $\mathrm{X}$ \\
\hline $\begin{array}{l}\text { Observations } \\
\text { Log Likelihood }\end{array}$ & $\begin{array}{c}1,288,443 \\
-7,991.354\end{array}$ & $\begin{array}{c}1,223,887 \\
-7,253.295\end{array}$ & $\begin{array}{c}977 \\
-632.021\end{array}$ & $\begin{array}{c}956 \\
-457.089\end{array}$ \\
\hline
\end{tabular}

${ }^{* * *} p<0.01,{ }^{* *} p<0.05,{ }^{*} p<0.1$.

Robust standard errors (clustered by county) in parentheses.

Race measured against white voters in Models $1-4$.

Party measured against Democrats in Models 2 and 4

Gender measured against females in Models 2 and 4 
In Model 1, Black voters are still highly over-represented among the wrongfully purged; Black voters were 21.3 percent more likely to be wrongfully purged than white voters. Model 2, however, indicates that much of this discrepancy can be explained by sociodemographic and geographic differences between the populations. Of course, that Black voters are overrepresented in populations where all voters are more likely to be wrongfully purged does obviate the fact that wrongful purges fall more frequently on this population. Models 3 and 4 indicate that wrongfully purged Black voters are far more likely (between 150 and 300 percent more likely) to see their provisional ballot rejected. Clearly, even when we assume that the data from the state on removal reasons is perfect - an assumption we know is untrue — wrongful purges fall disproportionately on Black North Carolinians. 


\section{References}

Ansolabehere, Stephen, and Eitan Hersh. 2010. "The Quality of Voter Registration Records: A State-by-State Analysis." CalTech / MIT Voting Technology Project. http://vote. caltech.edu/reports/6.

Ansolabehere, Stephen, and David M. Konisky. 2006. “The Introduction of Voter Registration and Its Effect on Turnout." Political Analysis 14 (1): 83-100. https://doi.org/10. 1093/pan/mpi034.

Ashenfelter, Orley, and Stanley Kelley. 1975. "Determinants of Participation in Presidential Elections." The Journal of Law and Economics 18 (3): 695-733. https://doi.org/10. $1086 / 466834$.

Boozer, Chelsea. 2016. "Error Flags Voters on Arkansas List; Thousands in Jeopardy of Having Their Registration Canceled." Arkansas Democrat-Gazette, July 25, 2016. https: //www.arkansasonline.com/news/2016/jul/25/error-flags-voters-on-state-list-201607/.

Brater, Jonathan, Kevin Morris, Myrna Pérez, and Christopher Deluzio. 2018. "Purges: A Growing Threat to the Right to Vote," 34.

Cao, Jian, Seo-young Silvia Kim, and R. Michael Alvarez. 2020. "Heterogeneity in Voter List Maintenance Practices: A Study of Florida Counties," April. https://doi.org/10. 33774/apsa-2020-rqn3n.

Enamorado, Ted. 2018. "Analysis | Georgia's 'Exact Match' Law Could Potentially Harm Many Eligible Voters." Washington Post, October 20, 2018. https://www.washingtonpost.com/news/monkey-cage/wp/2018/10/20/georgias-exactmatch-law-could-disenfranchise-3031802-eligible-voters-my-research-finds/.

Gerber, Alan S., and Donald P. Green. 2000. "The Effects of Canvassing, Telephone Calls, and Direct Mail on Voter Turnout: A Field Experiment." The American Political Science Review 94 (3): 653-63. https://doi.org/10.2307/2585837. 
Hajnal, Zoltan, Nazita Lajevardi, and Lindsay Nielson. 2017. "Voter Identification Laws and the Suppression of Minority Votes." Journal of Politics 79 (2): 363-79. https: //doi.org/10.1086/688343.

Hardy, Benjamin. 2016. "Data Mix-up from Ark. Secretary of State Purges Unknown Number of Eligible Voters." Arkansas Times. July 25, 2016. https://arktimes.com/arkansasblog/2016/07/25/data-mix-up-from-ark-secretary-of-state-purges-unknown-number-ofeligible-voters.

Herron, Michael C., and Daniel A. Smith. 2014. "Race, Party, and the Consequences of Restricting Early Voting in Florida in the 2012 General Election." Political Research Quarterly 67 (3): 646-65. https://doi.org/10.1177/1065912914524831.

Hicks, William D., Seth C. McKee, Mitchell D. Sellers, and Daniel A. Smith. 2015. "A Principle or a Strategy? Voter Identification Laws and Partisan Competition in the American States." Political Research Quarterly 68 (1): 18-33. https://doi.org/10.1177/ 1065912914554039.

Kimball, David C., Martha Kropf, and Lindsay Battles. 2006. "Helping America Vote? Election Administration, Partisanship, and Provisional Voting in the 2004 Election." Election Law Journal: Rules, Politics, and Policy 5 (4): 447-61. https://doi.org/10. $1089 /$ elj.2006.5.447.

Merivaki, Thessalia. 2019. "Access Denied? Investigating Voter Registration Rejections in Florida." State Politics 8 Policy Quarterly 19 (1): 53-82. https://doi.org/10.1177/ 1532440018800334 .

- 2020. "'Our Voter Rolls Are Cleaner Than Yours': Balancing Access and Integrity in Voter List Maintenance." American Politics Research, February, 1532673X20906472. https://doi.org/10.1177/1532673X20906472.

Merivaki, Thessalia, and Daniel A. Smith. 2016. "Casting and Verifying Provisional Ballots in Florida*." Social Science Quarterly 97 (3): 729-47. https://doi.org/10.1111/ssqu. 
12245.

—. 2020. "A Failsafe for Voters? Cast and Rejected Provisional Ballots in North Carolina." Political Research Quarterly 73 (1): 65-78. https://doi.org/10.1177/ 1065912919875816.

Morris, Kevin. 2019. "Voter Purge Rates Remain High, Analysis Finds." Brennan Center for Justice. August 1, 2019. https://www.brennancenter.org/our-work/analysis-opinion/ voter-purge-rates-remain-high-analysis-finds.

—. 2020. "Neighborhoods and Felony Disenfranchisement: The Case of New York City." Urban Affairs Review, May, 1078087420921522. https://doi.org/10.1177/ 1078087420921522 .

Olsen, Lise. 2012. “Texas' Voter Purge Made Repeated Errors.” Houston Chronicle. November 2, 2012. https://www.chron.com/politics/article/Texas-voter-purge-made-repeatederrors-4001767.php.

Pettigrew, Stephen, and Charles Stewart III. 2017. "Moved Out, Moved on: Assessing the Effectiveness of Voter Registration List Maintenance." SSRN Scholarly Paper ID 3044810. Rochester, NY: Social Science Research Network. https://papers.ssrn.com/ abstract $=3044810$.

Pew Center on the States. 2009. "Provisional Ballots: An Imperfect Solution." The Pew Charitable Trusts. https://www.pewtrusts.org/ /media/legacy/uploadedfiles/pcs assets/2009/elecprovballotbrief0709pdf.pdf.

Rocha, Rene R., and Tetsuya Matsubayashi. 2014. "The Politics of Race and Voter ID Laws in the States: The Return of Jim Crow?" Political Research Quarterly 67 (3): 666-79. https://doi.org/10.1177/1065912913514854.

Shaw, Daron, and Vincent Hutchings. 2013. "Report on Provisional Ballots and American Elections." http://web.mit.edu/supportthevoter/www/files/2013/08/Provisional- 
Ballots-Shaw-and-Hutchings.docx_.pdf.

Stewart III, Charles. 2018. "Is the EAVS a Reliable Guide to Voter List Maintenance?" SSRN Scholarly Paper ID 3238927. Rochester, NY: Social Science Research Network. https://doi.org/10.2139/ssrn.3238927.

2. 2019. "How Valid Are Voter Registration Statistics? A Demographic Approach for Assessing the Validity of EAVS Voter Registration Data." SSRN Scholarly Paper ID 3316422. Rochester, NY: Social Science Research Network. https://doi.org/10.2139/ ssrn.3316422.

Stuart, Guy. 2004. "Databases, Felons, and Voting: Bias and Partisanship of the Florida Felons List in the 2000 Elections." Political Science Quarterly 119 (3): 453-75. https: //doi.org/10.2307/20202391.

Ura, Alexa. 2019. "In Advisory, Texas Implies Its List of Thousands of Voters Flagged for Citizenship Reviews Could Include Naturalized Citizens." The Texas Tribune. February 1, 2019. https://www.texastribune.org/2019/02/01/texas-acknowledges-itslist-thousands-texas-voters-flagged-citizenship/.

Weaver, Russell. 2015. "The Racial Context of Convenience Voting Cutbacks: Early Voting in Ohio During the 2008 and 2012 U.S. Presidential Elections." SAGE Open 5 (3): 2158244015591825. https://doi.org/10.1177/2158244015591825.

Wolfinger, Raymond E., and Steven J. Rosenstone. 1980. Who Votes? A Yale Fastback. New Haven: Yale University Press. 